\title{
legelivet,
}

På disse sidene i Tidsskriftet - legelivet - finner du stoff om legers liv.

Her er det presentasjon av arbeidssteder, nyhetssaker, nye doktorgrader,

nye spesialister og minneord. Alt samlet på ett sted - så du kan følge enda bedre med.

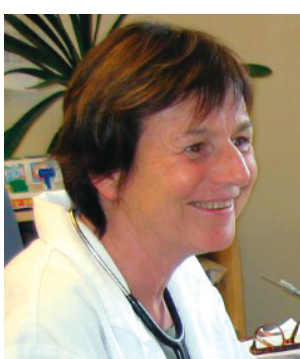

Elisabeth Swensen. Foto: Privat

Elisabeth Swensen (f. 1951) er kommuneoverlege og fastlege ved Seljord helsesenter.

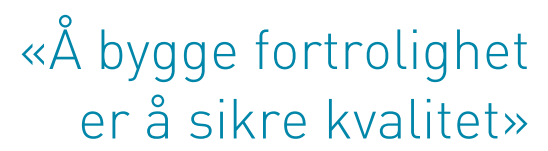

\section{En åpen dør}

Kvalitetssikring er mer enn å ha orden i permene.

Jeg hører til dem som aldri har knekket koden i kvalitetssjargongen, til tross for at jeg virkelig har forsøkt. Det blir mye sjekklister, flytskjemaer og skriftliggjøring som oppleves litt som rituelle knebøyninger for et eventuelt tilsyn. Jo da, vi har permene. Men vi er vel ikke akkurat stolte av dem.

Derimot leste jeg for mange år siden en studie der man hadde sett på utfallet av kirurgiske inngrep og klarte å vise at det gikk bedre dersom kirurgene faktisk likte hverandre og snakket sammen underveis i prosessen. På vårt helsesenter er vi mange profesjoner under samme tak: leger, sykepleiere, legesekretærer, fysioterapeuter, helsesøstre, jordmor og i varierende grad studenter og turnusleger. Det sier seg selv at vi er ulike, med forskjellige arbeidsmåter og preferanser. Som leder ser jeg mangfoldet som en verdi i seg selv, så lenge pasientene kan være trygge på at vi holder oss innenfor det som kalles «allment aksepterte faglige normer». Vi har faste legemøter, personalmøter, møter med eksterne samarbeidspartnere og fra tid til annen dagsseminarer der større tverrfaglige eller fagkulturelle temaer tas opp. Slik sett har vi både systemer og arenaer for det som må kunne kalles bygging av kvalitet.

Den viktigste kilden til kvalitet i det daglige er likevel to enkle, obligatoriske strukturelle grep som jeg som leder håndhever kon- sekvent: Alle dører til alle kontorer skal være åpne, med mindre det er grunn til å lukke dem. Det betyr at vi lukker døren når vi har pasienter, selvsagt, eller sitter i telefonen eller bare trenger litt fred. Men ellers sitter vi slik at vi med letthet kan oppsøke hverandre og gå ut og inn av hverandres kontorer for å få støtte og hjelp eller kanskje bare for å lufte en frustrasjon eller fortelle noe morsomt. Den andre regelen er at alle spiser lunsj sammenhver dag. Da sitter vi rundt det store bordet i kjøkkenet, med et litt for høyt støynivå, men med en klar fornemmelse av at «dette er vi sammen om». I lunsjen er det rom for å utveksle matoppskrifter, drøfte helseministerens forslag til sykehusstruktur, diskutere religion, ta opp irritasjonsmomenter som at kjøleskapet forsøples eller betro hverandre nyheter på kjærlighetsfronten. Én onsdag i måneden er det undervisningslunsj, ansvaret for tema går på omgang mellom avdelingene.

Å bygge fortrolighet er å sikre kvalitet. Å vite at man kan spørre hverandre om sånt man selv ikke er stødig på, er mangelvare i mange institusjoner. Det skal aldri være flaut å stille spørsmål eller be om hjelp. Trygghet $\mathrm{i}$ jobben er et felles anliggende.

Elisabeth Swensen elswense@online.no 